François Donati PH D MD, Jean-Guy Maille MD, Robert Blain MD, Marcel Boulanger MD, Philippe Sahab MD

\title{
End-tidal carbon dioxide tension and temperature changes after coronary artery bypass surgery
}

\begin{abstract}
Variations in end-tidal carbon dioxide partial pressure $\left(\mathrm{PETCO}_{2}\right)$ and lemperature were measured for six hours following coronary artery bypass surgery in wenty patients. In the recovery room, the patients were mechanically ventilated with a tidal volume of $12 \mathrm{ml} \cdot \mathrm{kg}^{-1}$. Arterial blood gases were drawn every two hours, and the respiratory frequency was adjusted to maintain arterial carbon dioxide pressure $\left(\mathrm{PaCO}_{2}\right)$ in the range of 30 $45 \mathrm{mmHg}$. Naso-pharyngeal temperature was recorded every 30 minutes, and PETCO $\mathrm{O}_{2}$ was measured continuously. The mean difference between temperaturecorrected arterial and end-tidal $\mathrm{CO}_{2}$ pressure measurements was $3.2 \mathrm{mmHg}(S D=2.8 ; r=0.963)$. This difference did not vary with time, temperature or $\mathrm{PCO}_{2}$. The largest temperature increases (mean $1.7^{\circ} \mathrm{C} /$ hour) occurred at a mean of 253 minutes after the end of surgery. End-tidal $\mathrm{PCO}_{2}$ increased markedly as temperature rose, in spite of a coincident increase in ventilation and then decreased as temperature stabilized. Large increases in $\mathrm{CO}_{2}$ production, caused by the metabolic demands during rewarming, most likely account for these changes. It is concluded that end-tidal $\mathrm{CO}_{2}$ recordings are reliable, and can help in maintaining normocarbia during the short but unstable period associated with rewarming following cardiac surgery.
\end{abstract}

\section{Key words}

ANAESTHESIA: cardiovascular; TEMPERATURE: body; VENTILATION: postoperative, carbon dioxide tension.

From the Department of Anaesthesia, Montreal Heart Institute, Montreal, Quebec, Canada.

Address correspondence to: Dr. J.G. Maillé, Montreal Heart Institute, 5000 east, Belanger Street, Montreal, Quebec, H1T 1C8, Canada.
End-tidal carbon dioxide pressure $\left(\mathrm{PeTCO}_{2}\right)$ has been used as an estimate of arterial carbon dioxide pressure $\left(\mathrm{PaCO}_{2}\right)$ in the intensive care setting and during anaesthesia. The mean arterial to end-tidal $\mathrm{PCO}_{2}$ difference has been reported by various authors to be 7.9 to $0.8 \mathrm{mmHg}$, depending on the circumstances. ${ }^{1-7}$ None of these reports include patients after extracorporeal circulation.

Patients undergoing coronary artery surgery lose heat because of prolonged anaesthesia and incomplete rewarming following cardiopulmonary bypass. ${ }^{8}$ Mechanical ventilation is usually continued for many hours after surgery because of thermal instability, haemodynamic instability and the respiratory depressant effect of previously administered narcotics. Because of the rapid changes which may be observed in these patients, continuous measurement of end-tidal $\mathrm{CO}_{2}$ may be more useful than the intermittent sampling of arterial blood gases. Furthermore, the time course and pattern of rewarming has not been described after cardiac surgery.

This study was designed to establish the correlation between end-tidal and arterial $\mathrm{PCO}_{2}$ in these patients, to observe temperature variations with time, and to correlate them with changes in endtidal $\mathrm{CO}_{2}$.

\section{Methods}

Twenty consecutive patients scheduled for myocardial revascularization were entered into the study. None had heart failure or pulmonary disease. Eighteen were male. Mean age was 59 years, with a standard deviation (SD) of nine years. Mean weight was $74 \mathrm{~kg}(\mathrm{SD}=12 \mathrm{~kg})$, and mean height was $163 \mathrm{~cm}(\mathrm{SD}=7 \mathrm{~cm})$. Preoperative medication consisted of beta-blockers (in 19 patients), nitrates (11), 
calcium entry blockers (5), diuretics (5), digitalis (2) and other antihypertensives (2). They were premedicated with hydroxyzine $50 \mathrm{mg}$ in the morning. One hour before surgery, they received scopolamine $0.4 \mathrm{mg}$ with morphine $0.1 \mathrm{mg} \cdot \mathrm{kg}^{-1}$ or pentobarbitone $2 \mathrm{mg} \cdot \mathrm{kg}^{-1}$ intramuscularly. Before induction of anaesthesia, a radial artery was cannulated and a pulmonary artery catheter was inserted via an internal jugular vein.

Anaesthesia was provided with diazepam 0.2 $\mathrm{mg} \cdot \mathrm{kg}^{-1}$ and fentanyl $50 \mu \mathrm{g} \cdot \mathrm{kg}^{-1}$. This was supplemented by isoflurane if required. Muscle relaxation was achieved with pancuronium 0.15 $\mathrm{mg} \cdot \mathrm{kg}^{-1}$. Duration of bypass was $38-178$ minutes (mean 104 minutes), and minimum temperature was $23.1-29.7^{\circ} \mathrm{C}$ (mean $26.2^{\circ} \mathrm{C}$ ). Patients were allowed to come off bypass when their nasopharyngeal and rectal temperatures exceeded $37^{\circ} \mathrm{C}$ and $33^{\circ} \mathrm{C}$ respectively. No patient required inotropic support. Hypertension, if present, was treated with either nitroglycerin or nitroprusside.

On arrival in the recovery room, patients were ventilated with a tidal volume of $12 \mathrm{ml} \cdot \mathrm{kg}^{-1}$, ten times per minute. This frequency was adjusted to maintain normocarbia or slight hypocarbia (30$45 \mathrm{mmHg}$ ), according to the results of arterial blood gases, which were drawn every two hours. The partial pressures of blood gases were measured at $37^{\circ} \mathrm{C}$ with a Radiometer model ABL-1 analyzer. Inspired oxygen concentration was 40 per cent initially and increased if necessary to maintain arterial $\mathrm{PO}_{2}$ above $100 \mathrm{mmHg}$. Inspired gases were humidified and their temperature was $28-29^{\circ} \mathrm{C}$ at the endotracheal tube. Patients were in the supine position with a 0 to $15^{\circ}$ head up tilt. They were lying on a water mattress (K-thermia), which warmed or cooled them if their rectal temperature, which was measured every hour with a mercury-in-glass thermometer, was less than $36.5^{\circ} \mathrm{C}$ or greater than $37.5^{\circ} \mathrm{C}$ respectively.

A Puritan-Bennett infrared absorption $\mathrm{CO}_{2}$ analyzer with a paper chart recorder was used to obtain continuous end-tidal measurements for at least six hours postoperatively. A calibration was done before each case, using air drawn through a $\mathrm{CO}_{2}$ absorber and with gas sampled from a five per cent $\mathrm{CO}_{2}$ cylinder. A naso-pharyngeal temperature probe (YSI instruments) was inserted and temperature was recorded every 30 minutes.

End-tidal $\mathrm{CO}_{2}$ pressure $(\mathrm{PETCO})$ was defined as the maximum expired $\mathrm{CO}_{2}$ fraction $\left(\mathrm{FeTCO}_{2}\right)$ times the dry gas pressure:

$\mathrm{PETCO}_{2}=\mathrm{FETCO}_{2} \times\left(\mathrm{P}_{\mathrm{B}}-\mathrm{P}_{\mathrm{H}_{2} \mathrm{O}}\right)$

where $\mathrm{P}_{\mathrm{B}}$ and $\mathrm{P}_{\mathrm{H}_{2} \mathrm{O}}$ represent atmospheric pressure and water vapour presure, respectively.

Maximum $\mathrm{CO}_{2}$ fraction was determined as the mean over $10-15$ breaths. The temperature correction for arterial $\mathrm{PCO}_{2}$ was obtained as follows:

$\mathrm{PaCO}_{2}$ (corr.) $=\mathrm{PaCO}_{2}$ (meas.) $\times 10 \mathrm{f}^{\Delta \mathrm{T}}$

where $\mathrm{PaCO}_{2}$ (corr) and $\mathrm{PaCO}_{2}$ (meas) referred to the temperature corrected and the measured $\mathrm{PaCO}_{2}$ respectively, $f$ is a correction factor and $\Delta T$ is the difference between the patient's temperature and $37^{\circ} \mathrm{C}$. Estimates of $\mathrm{f}$ have varied between 0.019 and $0.0233^{9.10} \mathrm{~A}$ value of 0.021 was used in our calculations.

The results are presented as mean values with the standard error of the mean as an index of dispersion. The relationship between two variables is expressed by a linear regression obtained by least mean squares. A correlation coefficient is obtained. The two variables are considered related when the slope of the regression line is significantly $(p<0.05)$ different from zero, using the paired Student's t test.

\section{Results}

There were 75 paired measurements of arterial and end-tidal $\mathrm{PCO}_{2}$. The mean difference, without temperature correction, was $5.4 \mathrm{mmHg}$ with a standard deviation of $3.7 \mathrm{mmHg}$. The value of this difference varied markedly with temperature $(r=0.75 ; p<$ 0.0001 ), within the range of 32.3 to $39.7^{\circ} \mathrm{C}$. When temperature corrections were applied to the arterial $\mathrm{PCO}_{2}$, the mean difference was reduced to 3.2 $\mathrm{mmHg}$, and the standard deviation was also smaller $(2.8 \mathrm{mmHg})$. This difference was independent of temperature $(\mathrm{r}=0.15 ; \mathrm{N}$.S.). It was also independent of time and $\mathrm{PCO}_{2}$. Temperature-corrected arterial and end-tidal values comelated very well with each other $(r=0.963)$ (Figure 1).

All patients were cold when they arrived in the recovery room. Their mean temperature was $34.1^{\circ} \mathrm{C}$, with a range of 32 to $36^{\circ} \mathrm{C}$. Six hours later mean temperature was $38.0^{\circ} \mathrm{C}$, with a range of 36.3 to $39.7^{\circ} \mathrm{C}$. The patients remained cold for a few hours after their admission to the recovery room. Then rapid rewarming took place and was complete 


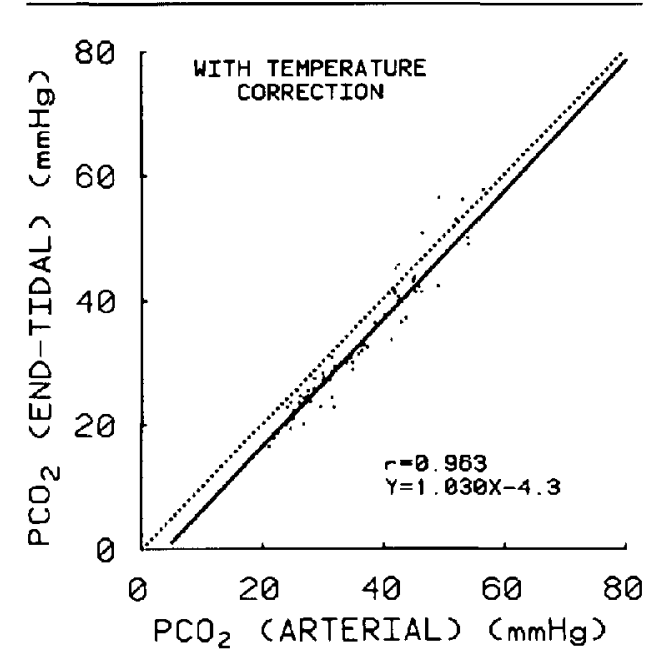

FIGURE 1 End-tidal $\mathrm{PCO}_{2}$ versus arterial $\mathrm{PCO}_{2}$ with temperature correction: 75 measurements in 20 patients. Dashed line is line of identity. Solid line is regression line obtained by the least squares regression method.

within a short period of time. The maximum temperature increase occurred at a mean time of 253 minutes after the end of surgery (range 120-420 minutes). At that time, the temperature increased at a mean rate of $1.7^{\circ} \mathrm{C}$ /hour (range $1.0-3.5^{\circ} \mathrm{C}$ hour) (Figure 2). Shivering was observed in all patients and this coincided with increasing temperatures.

End-tidal $\mathrm{CO}_{2}$ increased as temperature increased, in spite of coincident increases in ventilation (Figure 3). Twelve patients had an end-tidal $\mathrm{PCO}_{2}$ exceeding $45 \mathrm{mmHg}$. Two-hourly adjustments in ventilation were insufficiently frequent to prevent hypercapnia in these patients. When temperature stabilized again, a tendency to hypocapnia had to be compensated by decreasing ventilation. The shape of the expired $\mathrm{CO}_{2}$ curve for each breath was constant for each patient.

\section{Discussion}

This study demonstrated marked changes in temperature and carbon dioxide tension during the few hours after completion of cardiac surgery. In order to avoid the deleterious effects of both hypo- and hypercapnia, adjustments in ventilation should be made. Because these changes occur over a relatively short time period, the intermittent blood sam-

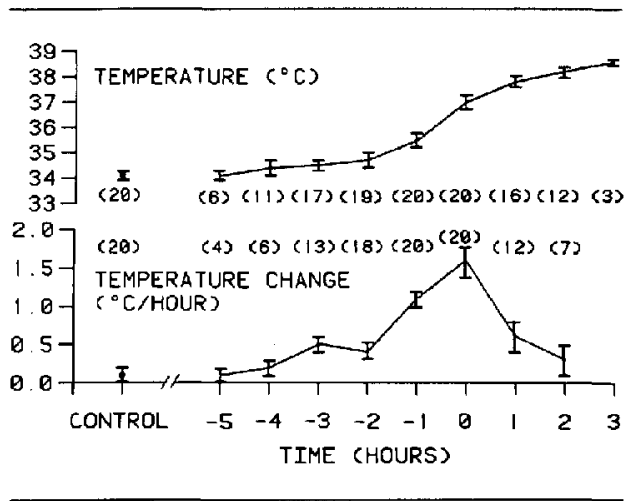

FIGURE 2 Temperature (top) and temperature change (bottom) as a function of time. Time zero is defined for each patient as the time of maximum temperature increase. Number of patients shown in parentheses. Bars indicate standard error of the mean. Control values were obtained immediately after arrival in the rccovery room.

pling of arterial blood gases every two hours is not frequent enough to insure optimum ventilatory management. The monitoring of end-tidal $\mathrm{CO}_{2}$ appears ideal in this setting because it is continuous and non-invasive, and it correlates closely with arterial $\mathrm{PCO}_{2}$. Furthermore, its use may reduce the need for arterial blood gas sampling.

The difference between arterial and end-tidal $\mathrm{PCO}_{2}$ depends on the importance of ventilation/perfusion (V/Q) abnormalities. This difference is about $1 \mathrm{mmHg}$ in the healthy erect individual. ${ }^{11}$ The difference of $3.2 \mathrm{mmHg}$ reported here most likely reflects the simultaneous influence of many factors on V/Q abnormalities, such as the increase in lung water following bypass, ${ }^{12}$ positive pressure ventilation, and the residual effects of the anaesthetic agents and muscle relaxants. ${ }^{13}$

The interpretation of temperature-corrected blood gases is controversial. ${ }^{14}$ It must be stressed, however, that end-tidal $\mathrm{PCO}_{2}$ as measured by $\mathrm{aCO}_{2}$ analyzer requires little temperature correction, of the order of 0.3 per cent per ${ }^{\circ} \mathrm{C}$ to account for the changes in vapour pressure with temperature. On the other hand, $\mathrm{PCO}_{2}$ in arterial blood varies by five per cent per ${ }^{\circ} \mathrm{C}$, and failure to make the correction can result in significant differences in patients with moderate hypo or hyperthermia. ${ }^{6}$ End-tidal $\mathrm{PCO}_{2}$. therefore, follows temperature-corrected arterial $\mathrm{PCO}_{2}$ closely.

Temperature increases occurred during a short 


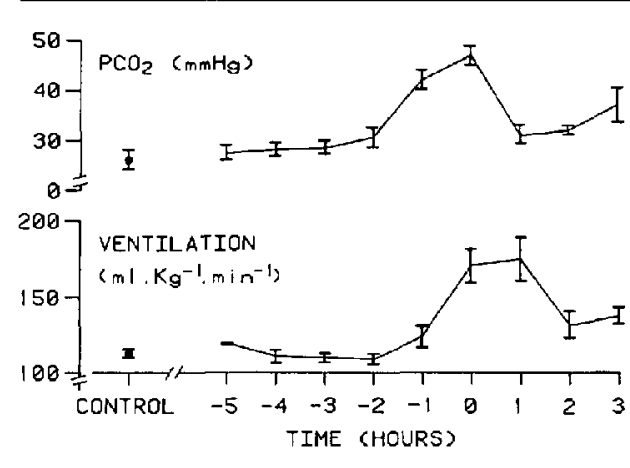

FIGURE 3 End-tidal $\mathrm{PCO}_{2}$ and ventilation as a function of time. Time zero is defined for each patient as the time of maximum temperature increase. Bars indicate standard error of the mean. Control values were obtained immediately after arrival in the recovery room.

period of time (1-2 hours), but many hours after completion of surgery. The large quantities of narcotics and muscle relaxants administered during cardiac anaesthesia undoubtedly played a role in delaying the thermogenic response. A more thorough rewarming when coming off bypass and aggressive rewarming during the early part of the recovery period should be expected to decrease the amount of heat which must be generated by the patient. In this regard, the use of heating mattresses in this study proved ineffective, as judged by the small increase in temperature observed in the early part of the recovery period.

The large increase in end-tidal $\mathrm{PCO}_{2}$, which coincides with increases in temperature, can theoretically arise from only three sources: a decrease in ventilation, an increase in $\mathrm{CO}_{2}$ production or an increase in dead space. Ventilation was actually increased. Dead space variations are expected to play a minor role, because no change in arterial to end-tidal $\mathrm{PCO}_{2}$ difference was detected, and no change in the shape of the end-tidal $\mathrm{CO}_{2}$ curve was observed. Furthermore, it is reasonable to assume that patients responded to hypothermia by generating heat, which is accomplished by utilizing more oxygen, thus increasing $\mathrm{CO}_{2}$ production. Assuming a constant dead space (tidal volume was kept constant throughout), the variations in $\mathrm{CO}_{2}$ production can be estimated (Figure 4). When compared to the immediate post-surgical period, maximum $\mathrm{CO}_{2}$

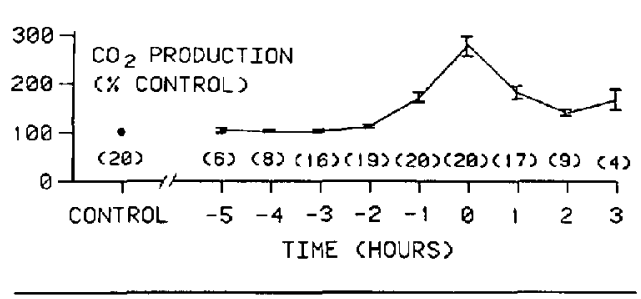

FIGURE 4 Estimated $\mathrm{CO}_{2}$ production (as a percentage of values on arrival in the recovery room), as a function of time. Time zero is defined for each patient as the time of maximum temperature increase. Bars indicate standard error of the mean.

production coincided with the maximum temperature rise in each patient. The mean maximum $\mathrm{CO}_{2}$ production was 285 per cent of its immediate post-surgical value (range $165-456$ per cent). When temperature reached a plateau, $\mathrm{CO}_{2}$ production stabilized again, but at a higher value than initially, most likely because of the higher metabolic rate associated with the greater body temperature. The estimates of $\mathrm{CO}_{2}$ production correlated very well with temperature increases (Figure 5), which indicates a heat production in proportion to the heat deficit. These increases in $\mathrm{CO}_{2}$ production after cardiac surgery are quantitatively similar to the

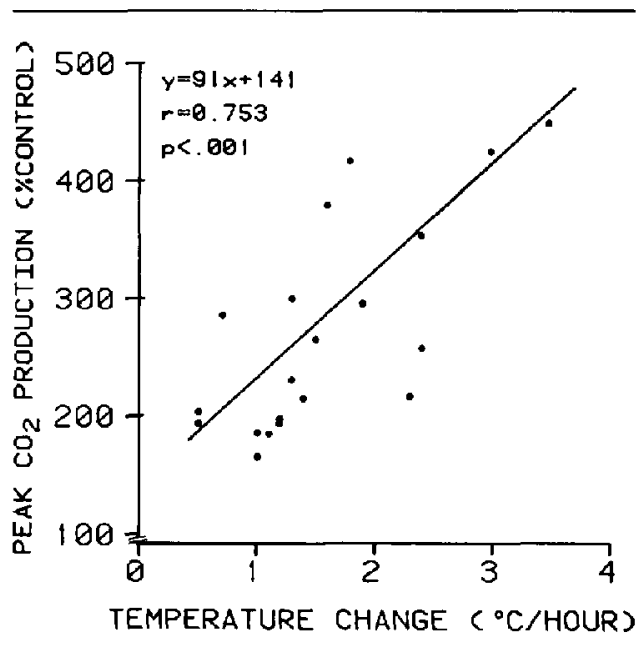

FIGURE 5 Estimated peak $\mathrm{CO}_{2}$ production, expressed as a percentage of initial value, versus maximum nasopharyngeal temperature increase in 20 patients. 
increases in oxygen consumption measured shortly after non-cardiac surgery. ${ }^{15}$

In addition to the deleterious effects of hypercapnia, such an increase in $\mathrm{CO}_{2}$ production may have adverse effects on the patients. Oxygen must be delivered to tissues in increased quantities and this must be accomplished by increasing cardiac output and/or decreasing mixed venous oxygen content. The former might not be well tolerated by patients with cardiovascular disease, and the latter will decrease arterial oxygen saturation if the lungs have significant $\mathrm{V} / \mathrm{Q}$ abnormalities. The haemodynamic consequences of rewarming deserve further investigation. Passive rewarming is likely to blunt these responses, and a search for the best method to accomplish this deserves to be undertaken. Another approach would consist of paralyzing and sedating patients until passive rewarming is effective in achieving normal temperatures, as has been used successfully in patients after major non-cardiac surgery. ${ }^{16}$ Until the effectiveness of these measures are evaluated with regard to their complications, end-tidal $\mathrm{CO}_{2}$ measurements can be regarded as useful and reliable guides in the necessary adjustments of ventilation which are required after coronary artery surgery.

\section{References}

1 McAslan TC. Automated respiratory gas monitoring of critically injured patients. Crit Care Med 1976; 4: $255-60$.

2 Riker JB, Haberman B. Expired gas monitoring by mass spectrometry respiratory intensive care unit. Crit Care Med 1976; 4: 223-9.

3 Yakulis R, Snyder JV, Powner D et al. Mass spectrometry monitoring of respiratory variables in an intensive care unit. Resp Care 1978; 23: 671-9.

4 Nunn JF, Hill $D W$. Respiratory dead space and arterial to end-tidal $\mathrm{CO}_{2}$ tension difference in anaesthetized man. J Appl Physiol 1960; 15: 383-9.

5 Takki S, Aromaa V, Kanste A. The validity and usefulness of the end-tidal $\mathrm{PCO}_{2}$ during anaesthesia. Ann Clin Res 1972; 4: 278-84.

6 Whitesell $R$, Asiddao $C$, Gollman $D$ et al. Relationship between arterial and peak expired carbon dioxide pressure during anaesthesia and factors influencing the difference. Anesth Analg 1981; 60: 508-12.
7 Reamer DB, Francis D, Philip JH, Gabel RA. Variation in $\mathrm{PCO}_{2}$ between arterial blood and peak expired gas during anaesthesia. Anesth Analg 1983; 62: 1065-9.

8 David FM, Parimelzhagan KN, Harris EA. Thermal balance during cardiopulmonary bypass with moderate hypothermia in man. Br J Anaesth 1977; 49: $1127-32$

9 Nunn IF, Bergman NA, Bunatyan A et al. Temperature coefficients for $\mathrm{PCO}_{2}$ and $\mathrm{PO}_{2}$ of blood in vitro. J Appl Physiol 1965; 20: 23-6.

10 Bergman NA. Temperature coefficients for $\mathrm{PCO}_{2}$ and $\mathrm{PO}_{2}$ in bloods with varying acid-base status. J Appl Physiol 1968; 24: 225-8.

11 West JB. Regional differences in gas exchange in the lung of erect man. J Appl Physiol 1962; 17: 893-8.

12 Byrick RJ, Kay JC, Noble WH. Extravascular lung water accumulation in patients following coronary artery surgey. Can Anaesth Soc J 1977; 24: 332-45.

13 Rehder $K$, Sessler AD, Marsh M. General anaesthesia and the lung. Am Rev Respir Dis 1975; 112: 541-63.

14 Ream AK, Reilz BA, Silverberg G. Temperature correction of $\mathrm{PCO}_{2}$ and $\mathrm{pH}$ in estimating acid-base status: an example of the emperor's new clothes? Anesthesiology 1982; 56: 41-4.

15 Bay J, Nunn JF, Prys-Roberts C. Factors influencing $\mathrm{PO}_{2}$ during recovery from anaesthesia. $\mathrm{Br} \mathrm{J}$ Anaesth 1968; 40: 398-407.

16 Rodriguez JL, Weissman C, Damask MC, Askanazi $J$, Hyman AI, Kinney JM. Physiologic requirements during rewarming: suppression of the shivering response. Crit Care Med 1983; 11: 490-7. 
Résumé

Chez vingt malades ayant subi des pontages aortocoronariens, nous avons mesuré les variations des pres. sions de gaz carbonique en fin d" expiration $\left(\mathrm{PETCO}_{2}\right)$ et les changements de température au cours des six premières heures post-opératoires. Ces malades étaient ventilés mécaniquement et leur volume courant était de $12 \mathrm{ml} \cdot \mathrm{kg}^{-1}$. Les gaz du sang artériel étaient analysés aux deux heures et la fréquence respiratoire ajustée de façon à maintenir un $\mathrm{PaCO}_{2}$ entre 30 et $45 \mathrm{mmHg}$. La température naso-pharyngée était notée aux trente minutes et la $\mathrm{PETCO}_{2}$ mesurée de façon continue.

Lorsque la $\mathrm{PaCO}_{2}$ est corrigée en fonction de la température, la différence moyenne entre cette $\mathrm{PaCO}_{2}$ et la $\mathrm{PETCO}_{2}$ est de $3.2 \mathrm{mmHg}$ ( $\mathrm{SD}=2.8 ; r=0.963$ ). Cette différence n'est pas influencée par le temps, la température ni les valeurs de $\mathrm{PCO}_{2}$. Vers la quatrième heure après la fin de la chirurgie, la température corporelle s'élève rapidement (en moyenne de $1.7^{\circ}$ Cheure). La PETCO ${ }_{2}$ s'accroît de façon marquée au moment de l'élévation de température, malgré une augmentation concomitante de la ventilation; puis la $\mathrm{PETCO}_{2}$ diminue torsque la température corporelle se stabilise. Ces changements semblent être dus à une augmentation importante de la production de $\mathrm{CO}_{2}$, suite à des demandes métaboliques accrues au cours du réchauffement. Donc, l'enregistrement continu du $\mathrm{CO}_{2}$ en fin d'expiration $\left(\mathrm{PETCO}_{2}\right)$ est une méthode fiable qui peut aider à maintenir une normocarbie au cours de la période courte mais instable qui accompagne le réchauffement. 